\title{
Spirits of the Air: Birds and American Indians in the South
}

Shepard Krech III. 2009. University of Georgia Press, Athens. Pp. 245, copiously illustrated. \$44.95 (hardbound). ISBN-13 978-0-8203-2815-7.

\author{
Reviewed by E. N. Anderson ${ }^{1}$ \\ Reviewer Address: ${ }^{1}$ Department of Anthropology, University of California, Riverside, Riverside, California 92521
}

Received: March $26^{\text {th }} 2009$

Published: August $4^{\text {th }} 2010$
Volume 1:16-17

(C) 2010 Society of Ethnobiology

areas still teeming with birds in my youth have achieved something very close to "silent spring" now.

Krech summarizes this literature under several heads. Most obvious, of course, is "subsistence." Given the vast numbers of birds, it is not surprising that the Native peoples depended heavily on them for food, as all early sources reported. Hunting with blowguns was important and well-described here. Turkeys were especially important, but ducks and the now-extinct passenger pigeon contributed heavily. Krech is properly skeptical about recent claims that passenger pigeons may have become vastly more common after contact, though they probably rebounded somewhat (see p. 37). Archaeology does not always show this. I believe the reason is poor preservation of bones in that climate.

Next comes "material culture." Feathers were and are extremely important. Bones were used. Often a whole bird skin was used as an ornament or symbol. Not all bird uses involved killing; purple martin gourds were set up to encourage this bird to live around houses, where it drove away avian pests and ate insects.

Many chapters on symbol, religion, medicine, and myth follow. Given the fragmentary documentation, it is amazing that we know so much. Folk taxonomy is largely lost, but beliefs were often noted by early writers. Many ideas concern owls and other night birds, which are not always bad omens. As elsewhere in the world, eagles are the symbols of strength, hawks of predation, vultures of uncleanness-but vultures were creators and powerful helpers as well. Other birds figure less importantly. We have little record of smaller birds, though no one missed the mockingbird's singing ability or the jay's noisiness and cleverness. The Native peoples surely had far more knowledge, especially of smaller birds, than was recorded; most of the ethnoornithology must have been lost. Perhaps some manuscript record(s) will still turn up. 
I am struck by some similarities to Yucatec Maya beliefs (Anderson and Medina Tzuc 2005). Kingbirds were used in love magic by the Cherokee (p. 161) as they are today by the Yucatec. Woodpeckers were spiritually important in the south, as they still are in Yucatan. Most impressive are similarities of southern beliefs about the large woodpeckers, notably the ivorybill, to material in the Ritual of the Bacabs, a truly bizarre and only partially comprehensible Maya text on magical healing. Dating to around 1567, Ritual of the Bacabs survives in a copy from the late $18^{\text {th }}$ century, discovered in 1914-15 (see Arzápalo Marín 1987). It details many magical beliefs about the large woodpeckers, including the Guatemalan Ivorybill and the Lineated, collectively kolonte' in Maya, which correspond closely to the Ivorybill and Pileated of the southeastern United States. Jays, hawks, night birds (pauraques in the Bacabs, whippoorwills in the South), doves, large flycatchers, and other birds also figure in both the Bacab rituals and the southern Native religious and healing beliefs. It seems beyond doubt that the correspondences, especially in regard to the woodpeckers, show some cultural relationship. I am not aware of similar beliefs in central or north Mexico. The blowguns are another point of contact; they were once important to Yucatec hunters. Contact through the Caribbean or directly by sea is implied.

Krech discusses "human impact on birds" on pp. 175-190. The southern peoples had no domesticated birds; evidently there were enough wild turkeys that they felt no need of picking up the Mexican domesticated form. There is nothing in the texts about management of wild populations of birds, or, for that matter, deer or other mammals. Krech takes this to mean there probably was no idea of conserving or sustainable management (cf. Krech 1999). "Absence of evidence is not evidence of absence," however, and we have only late and unsystematic accounts of badly shattered populations. A belief similar to the Maya belief in the spirit protector of wild turkeys (and probably other game birds), sometimes called the Leaflitter Turkey, would probably not have survived. The Maya do not "conserve" in the modern sense, but they used to hunt conservatively and responsibly, killing no more than immediately needed, and the forest spirits would punish those who overhunted (Anderson and Medina Tzuc 2005). This sort of attitude would not last long in a Europeanized world. In regard to deer, the "deerskin trade" (described in Krech's book, with reference to a large literature) dominated Native economics in the $18^{\text {th }}$ century, and surely would have led to loss of conservation ideology. We will probably never know whether bird hunting was regulated or not.

A few minor cautions are in order. One is that evaluation of sources is not always ideal. We are not given much assessment of the relative reliability of the early works. Also, Krech does not mention that Theodore De Bry's late-16 $6^{\text {th }}$ century etchings, based on contemporary drawings, were heavily reworked to resemble Classical-style models in De Bry's studio. Use with caution. A minor error identifies the European "night raven" as the bittern (p. 24); it is the Blackcrowned Night-heron (Nycticorax nycticorax in Latin, doubling an old European name, Greek for "night raven").

Ethnobiology books are catching on as coffee tablers. Many spectacularly beautiful ethnobiological works have crossed my desk recently, ranging from Dave Yetman's superb book about columnar cacti (Yetman 2007) to Anthony Miller and Miranda Morris' Ethnoflora of the Soqotra Archipelago (2004). This is a worthy addition.

\section{References Cited}

Anderson, E. N., and Felix Medina Tzuc. 2005. Animals and the Maya in Southeast Mexico. University of Arizona Press, Tucson.

Arzápalo Marín, Ramón. 1987. El Ritual de los Bacabes. UNAM, Mexico City.

Krech, Shepard, III. 1999. The Ecological Indian: Myth and Reality. W. W. Norton, New York.

Miller, Anthony G., and Miranda Morris. 2004. Ethnoflora of the Soqotra Archipelago. Royal Botanic Garden Edinburgh, Edinburgh.

Sauer, Carl. 1971. Sixteenth Century North America: The Land and the People as Seen by Europeans. University of California Press, Berkeley.

Yetman, David. 2007. The Great Cacti: Ethnobotany and Biogeography. University of Arizona Press, Tucson. 